\title{
Evaluation of ecological niches of abundant species of Poecilus and Pterostichus (Coleoptera: Carabidae) in forests of steppe zone of Ukraine
}

\author{
Viktor V. Brygadyrenko
}

Brygadyrenko V. V. 2016: Evaluation of ecological niches of abundant species of Poecilus and Pterostichus (Coleoptera: Carabidae) in forests of steppe zone of Ukraine. - Entomol. Fennica 27: 81-100.

This article analyses abundances of seven Poecilus and Pterostichus species sampled from 836 forest sites located in five geographical regions of the steppe zone of Ukraine. The abundances are analysed in relation to eight forest conditions. New information about associations of the following five species was found. Poecilus versicolor was most abundant in sparse forest sites and on moist sandy soil. Pterostichus melanarius reached its maximum abundance on sites with a thick litter layer, mesohygrophilous condition, clay soils and a sparse herbaceous layer. Pterostichus niger reached maximum abundance in forests with mesohygrophilous and hygrophilous conditions and on sandy loam soils. Abundance of Pterostichus oblongopunctatus was at the highest on sites with a closed tree canopy, a thin litter layer and loamy soils of average salinity. Pterostichus ovoideus was most abundant in forests with low to average litter depth, hygrophilous conditions and loamy soils of low to average salinity. For Poecilus sericeus and Poecilus cupreus the results of this study agreed with the published information.

V. V. Brygadyrenko, Department of Zoology and Ecology, Oles' Honchar Dnipropetrovsk National University, pr. Gagarina, 72, Dnipropetrovsk, 49010, Ukraine; E-mail:brigad@ua.fm

Received 21 November 2015, accepted 22 March 2016

\section{Introduction}

Many species of ground-dwelling invertebrates are very sensitive to changes in environmental conditions, while others are less demanding. For every species in every ecosystem, there is a specific set of limiting factors (Thiele 1977). However, because of the sheer variety of elements in a given ecosystem, it is exceedingly difficult to identify precisely which of the many factors is a probable, as opposed to merely a potential, limiting factor (Hutchinson 1957). The task of identi- fying limiting ecological factors can only be addressed through extensive and carefully planned field research. This requires a very large number of sample plots, preferably in the order of magnitude of several hundreds (Brygadyrenko 2006). This gives the best chance of finding sites which collectively represent the full range of values for a studied ecological factor in a given climatic zone or geographical region.

The range of tolerance of certain ground beetle species for a particular ecological factor can vary considerably. Thus, simple, unambiguous 
assessments of a species' preferences (for example, moisture conditions) do not often provide an accurate description of the situation (Thiele 1977, Kryzhanovskij 1983). Rather, each ecological factor should be defined more precisely through application of a range of gradations and this should be incorporated into the research. This is inseparably linked with the number of studied sample sites and the species' frequency of occurrence (i.e. $\%$ of the sampled plots where a given species is found). Of course, it is easier to numerically assess the relationship of abundant ground beetle species to a certain ecological factor than the relationship of rare ones. This is why 7 common species were chosen for this study (Sharova et al. 1998, Brygadyrenko 2003). The analyzed species were Poecilus cupreus Linnaeus, 1758, $P$. versicolor (Sturm, 1824), P. sericeus (Fischer von Waldheim, 1823), Pterostichus melanarius (Illiger, 1798), P. niger (Schaller, 1783), P.oblongopunctatus (Fabricius, 1787) and $P$. ovoideus (Sturm, 1824).

For studying occurrences of the 7 abundant ground beetle species, eight ecological factors important in forest ecosystems were examined: type of forest, tree crown density, herbaceous layer density, litter depth, moisture conditions, soil texture and salinity, and abundance of ants. In conditions of insufficient moisture in the steppe zone of Ukraine, populations of invertebrate species are subjected to severe stress (Kul'bachko et al. 2014, 2015). Accordingly, moisture is the fundamental limiting factor. A dense tree crown layer and a thick litter layer can act as considerable compensating factors for the lack of moisture in the surrounding environment. The influences of moisture, tree crown density and litter depth are modified by the herbaceous layer, soil texture and salinity (Brygadyrenko 2015a). All these factors may vary spatially and temporally and cause their influence on the ground-dwelling invertebrates, including ground beetles. In addition, the presence of ants shows a strong correlation with the composition of ground beetle populations (Hawes et al. 2002, Reznikova \& Dorosheva 2004). The aim of this article is to find associations of the 8 above-mentioned ecological factors with the 7 ground beetle species of the Pterostichini tribe, which are dominant in forest ecosystems of the steppe zone of Ukraine.

\section{Materials and methods}

The material was collected from 836 sample plots (Fig. 1), located in five geographical regions (Dnipropetrovsk, Zaporizhia, Mykolaiv, Donetsk and Kharkiv) of Ukraine's steppe zone between 2001 and 2014 (Brygadyrenko 2014, $2015 \mathrm{a}, \mathrm{b}, \mathrm{c})$. These plots varied considerably in size, according to the extent of the forest or tree line plantation where they were located. In most

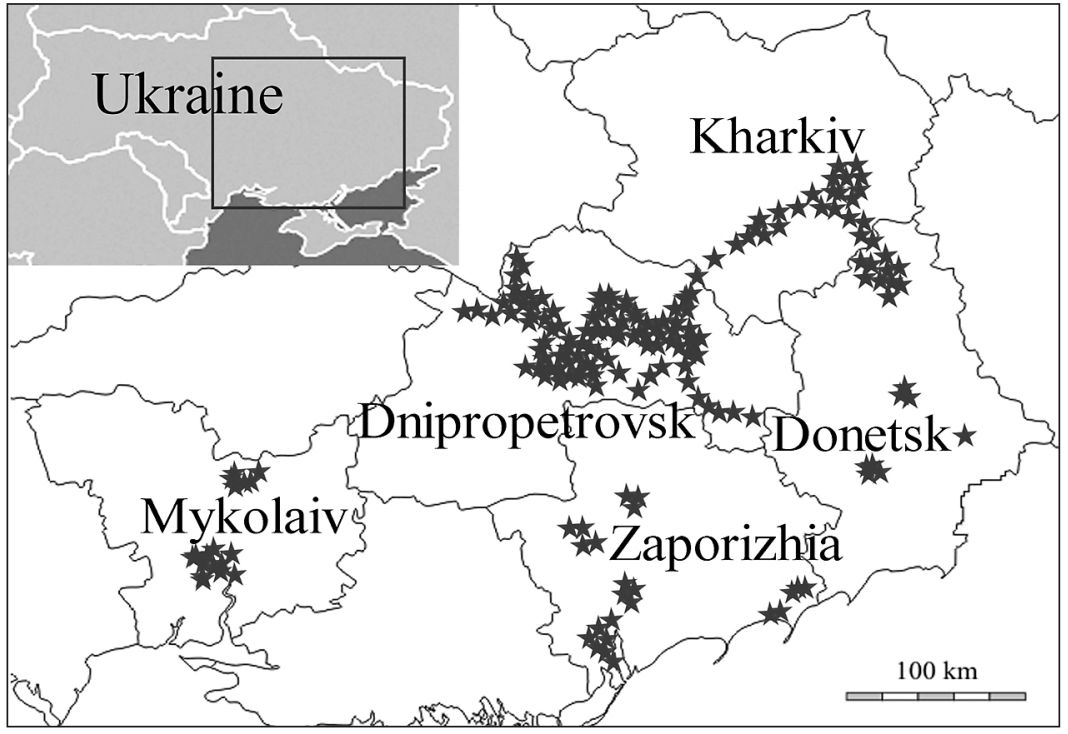

Fig. 1. Map of sample plots indicated by a star, located in five geographical regions of Ukraine: Dnipropetrovsk (568 plots), Zaporizhia (70), Mykolaiv (21), Donetsk (83) and Kharkiv (94). 
Table 1. Gradients of ecological factors with numbers of study plots (total 836) in forest ecosystems of the steppe zone of Ukraine. For explanations of gradients, see Fig. 2.

\begin{tabular}{lcccccrrr}
\hline $\begin{array}{l}\text { Gradient } \\
\text { of factor }\end{array}$ & $\begin{array}{c}\text { Tree } \\
\text { crown } \\
\text { density }\end{array}$ & $\begin{array}{c}\text { Type of } \\
\text { forest } \\
\text { ecosystem }\end{array}$ & $\begin{array}{c}\text { Density of } \\
\text { herbaceous } \\
\text { layer }\end{array}$ & $\begin{array}{c}\text { Thickness } \\
\text { of } \\
\text { litter }\end{array}$ & $\begin{array}{c}\text { Moisture } \\
\text { conditions }\end{array}$ & $\begin{array}{c}\text { Soil } \\
\text { texture }\end{array}$ & $\begin{array}{c}\text { Soil } \\
\text { salinity }\end{array}$ & $\begin{array}{c}\text { Abun- } \\
\text { dance } \\
\text { of ants }\end{array}$ \\
\hline 1 & 197 & 27 & 249 & 334 & 266 & 125 & 176 & 428 \\
2 & 46 & 128 & 143 & 234 & 305 & 51 & 125 & 229 \\
3 & 118 & 681 & 70 & 173 & 87 & 125 & 464 & 110 \\
4 & 277 & n. a. & 134 & 53 & 107 & 535 & 71 & 45 \\
5 & 198 & n. a. & 240 & 42 & 71 & n. a. & n. a. & 24 \\
\hline
\end{tabular}

n. a. - not analysed.

cases, usually in forests, the plot was about $10,000 \mathrm{~m}^{2}$, whereas in linear windbreak plantations the plot sizes varied from 1,000 to 15,000 $\mathrm{m}^{2}$. This paper is a part of a wider study which took into account the origin of the forests (whether they are natural forests, usually not primeval but at least three generations old, or plantations, the oldest of which dates from the 1890s), geomorphological factors (whether they are floodplain forests, ravine forests, or plateau forests), nature of the soil (chernozem, floodplain soils of different types, with different depths of humus horizon), phytocenotic characteristics (composition of the tree, shrub and herbaceous layers) and type of forest ecosystem. All the plots studied in this paper were classified using the following eight ecological factors:

- Tree crown density in percentage (average of five random measurements for each collection plot: $1: \leq 20 \%, 2: 21-40 \%, 3: 41-60 \%, 4$ : $61-80 \%, 5: \geq 81 \%$ )

- Type of forest ecosystem (1: pine, 2: mixed, 3: broad-leaved forest)

- Density of the herbaceous layer in percentage (average of five measurements for each collection plot: $1: \leq 20 \%, 2: 21-40 \%, 3: 41-$ $60 \%, 4: 61-80 \%, 5: \geq 81 \%$ )

- Depth of the litter in millimeters (average of ten random measurements for each collection plot; analysis made using five $10 \mathrm{~mm}$ classes of depth: $1: \leq 10 \mathrm{~mm}, 2: 11-20,3: 21-30,4$ : $31-40,5: \geq 41 \mathrm{~mm})$

- Moisture conditions (using indicator species of the herbaceous layer, the same as used in assessment of the density of this layer, according to the scale devised by Belgard
(1950) for the steppe zone of the Soviet Union: 1: xeromesophilous, 2: mesophilous, 3 : hygromesophilous, 4: mesohygrophilous, 5: hygrophilous)

- Texture of the soil horizon (from samples of $20 \mathrm{~cm}$ in depth, obtained from the soil dug for each of the 10 pit-fall traps per plot: 1: sandy, 2: sandy loam, 3: loam, 4: clay)

- Soil salinity (using the same herbaceous layer indicator species that were used for defining the moisture conditions, according to Belgard's (1950) scale: 1: trophotopes AB, B, $\mathrm{C}$; low salinity, 2: Dc, Dac; average salinity or slightly below, 3: Dn; above average salinity, 4: De, E; high to extremely high salinity)

- Abundance of ants (according to the results of counts from pit-fall traps on a logarithmic scale: $1: \leq 4,2$ : 5-16, 3: 17-64, 4: 65-256, 5: $\geq 256$ individuals/10 trap-days)

The number of study plots according to each ecological factor and its gradient in forest ecosystems is shown in Table 1.

The ground beetles were collected using 10 pit-fall traps in each plot, made each made of 0.51 glass jar (with $20 \% \mathrm{NaCl}$ solution). They were placed in a line at a distance of $2-10 \mathrm{~m}$ from one to another. Depending on the amount of precipitation, the traps were checked every $5 \mathrm{~d}$. This article analyses the results from each collection site for a $20 \mathrm{~d}$ period close to the middle of June, the exact dates varying from year to year. This particular period was chosen because in steppe forests there is still a high number of species with a spring period of activity (Brygadyrenko 2015a, b), and at the same time, a sufficiently high number of species with a summer-autumn period of 
Table 2. Statistical significances of associations of Pterostichini beetles with eight ecological factors in forest ecosystems of the steppe zone of Ukraine based on the analyses of 836 samples from pitfall traps. For exact ANOVA results, see Figs. 2-8.

\begin{tabular}{|c|c|c|c|c|c|c|c|c|}
\hline Species & $\begin{array}{c}\text { Tree } \\
\text { crown } \\
\text { density }\end{array}$ & $\begin{array}{c}\text { Type of } \\
\text { forest } \\
\text { ecosystem }\end{array}$ & $\begin{array}{c}\text { Density of } \\
\text { herbaceous } \\
\text { layer }\end{array}$ & $\begin{array}{c}\text { Thickness } \\
\text { of } \\
\text { litter }\end{array}$ & $\begin{array}{l}\text { Moisture } \\
\text { conditions }\end{array}$ & $\begin{array}{c}\text { Soil } \\
\text { texture }\end{array}$ & $\begin{array}{c}\text { Soil } \\
\text { salinity }\end{array}$ & $\begin{array}{l}\text { Abun- } \\
\text { dance } \\
\text { of ants }\end{array}$ \\
\hline Poecilus cupreus & * & n.s. & n.s. & n.s. & n.s. & n.s. & n.s. & n.s. \\
\hline P. versicolor & * & n.s. & n.s. & n.s. & * & * & n.s. & n.s. \\
\hline P. sericeus & n.s. & n.s. & n.s. & n.s. & n.s. & n.s. & n.s. & n.s. \\
\hline Pterostichus melanarius & n.s. & * & * & * & * & * & * & n.s. \\
\hline P. niger & n.s. & n.s. & n.s. & n.s. & * & * & n.s. & n.s. \\
\hline P. oblongopunctatus & * & n.s. & n.s. & * & n.s. & * & * & n.s. \\
\hline P. ovoideus & n.s. & n.s. & n.s. & * & * & * & * & n.s. \\
\hline
\end{tabular}

* and n.s.: significant $(P<0.00625)$ and insignificant $(P \geq 0.00625)$ association of the ecological factors after Bonferroni correction for eight ANOVAs for each species.

activity. For the analyses, the numbers of each species of ground beetle at each plot were calculated for uniform time periods (individuals per 10 trap-days), i.e. the total numbers from the 10 traps of the $20 \mathrm{~d}$ collection periods were divided by twenty.

The number of individuals for the different factor gradations was compared using ANOVA in Statistica 8.0. A large number of ANOVAs (8 for each ground beetle species, Figs. 2-8) was performed, so Bonferroni tests were applied to adjust the $\mathrm{P}$ values. Therefore, in Figs. $2-8$ only $\mathrm{P}$ values less than $0.00625(=0.05 / 8)$ were considered statistically significant.

In order to find out relative similarity of the distributions of the ground beetle species in the forest ecosystems of the steppe zone of Ukraine, a cluster analysis with linkage distance was performed (single linkage, Euclidean distances, Statistica 8.0). For this analysis, the raw data of the abundances were normalized: $(x i-x) / S D$, where $x i$ is the number of individuals for the separate ecosystems, $x$ is the average number of individuals for all ecosystems, and SD is the standard deviation of the number of individuals for all forest ecosystems.

\section{Results}

Table 2 provides an overall comparison of the distribution of the different ground beetle species of the tribe Pterostichini in the studied plots in the forests of the steppe zone in Ukraine. Soil texture was associated with the abundance of 5 of the 7 studied species, moisture conditions were associated with the abundance of 4 , soil salinity, tree crown density and depth of the litter were associated with the abundance of 3 , and density of the herbaceous layer and type of forest ecosystem were correlated with the abundance of 1 species. The abundance of the analyzed species varied significantly in response to $0-6$ out of the 8 analyzed ecological factors. Pterostichus melanarius was the species with most associations (6) with the studied ecological factors.

The abundance of Poecilus cupreus was significantly higher in conditions of low tree crown density (up to $20 \%$, Fig. 2a). Its frequency of occurrence in the total number of plots was $2.6 \%$ and its average abundance in the total number of plots was $0.027 \pm 0.228$ individuals/ 10 trap-days.

Poecilus versicolor reached its maximum abundance on sites with 20-40\% tree crown density (Fig. 3a), hygrophilous moisture conditions (Fig. 3e) and on sandy soils (Fig. 3f). Its frequency of occurrence was $7.6 \%$ and the average abundance was $0.081 \pm 0.792$ individuals $/ 10$ trap-days.

Poecilus sericeus showed no significant correlation in abundance with any of the studied ecological conditions. It was slightly more numerous than average in areas with low tree crown density (Fig. 4a), with average numbers of ants (Fig. 4h), and in xerophilous and mesophilous moisture conditions (Fig. 4e). Its frequency of occurrence was $2.1 \%$. Its average abundance was $0.052 \pm$ 0.551 individuals/ 10 trap-days. 
Fig. 2. Association of forest ecosystem conditions with Poecilus cupreus as means \pm 1.96 SD of numbers of ground beetles / 10 trap-days, and results of ANOVAs. - a. Tree crown density $(1: \leq$ 20\%, 2: $21-40 \%, 3$ : 41-60\%, 4: 61-80\%, 5: $\geq 81 \%$ ). - b. Type of forest ecosystem (1: pine, 2: mixed, 3: broadleaved forest). - c. Density of herbaceous layer cover $(1: \leq 20 \%$, 2: $21-40 \%, 3: 41-60 \%$, $4: 61-80 \%, 5: \geq 81 \%)$. $-\mathrm{d}$. Thickness of litter $(\mathrm{mm})(1: \leq 10,2: 11-$ 20, 3: 21-30, 4: 31-40, $5: \geq 41)$. - e. Moisture conditions (1: xeromesophilous, 2: mesophilous, 3: hygomesophilous, 4: mesohygrophilous, 5: hygrophilous). - $f$. Soil texture (1: sandy, 2 : sandy loam, 3: loam, 4: clay). -g. soil salinity (1: trophotopes, low salinity, 2: average salinity or slightly below, 3: above average salinity, 4 : high to extremely high salinity ). - h. Abundance of ants as individuals / 10 trap-days $(1: \leq 4,2: 5$ 16, 3: 17-64, 4: 65$256,5: \geq 256)$. ANOVA results shown in bold are considered significant, after Bonferroni correction for eight ANOVAs; in these cases, letters $a$ and $b$ mark differences between the values (Tukey's test).
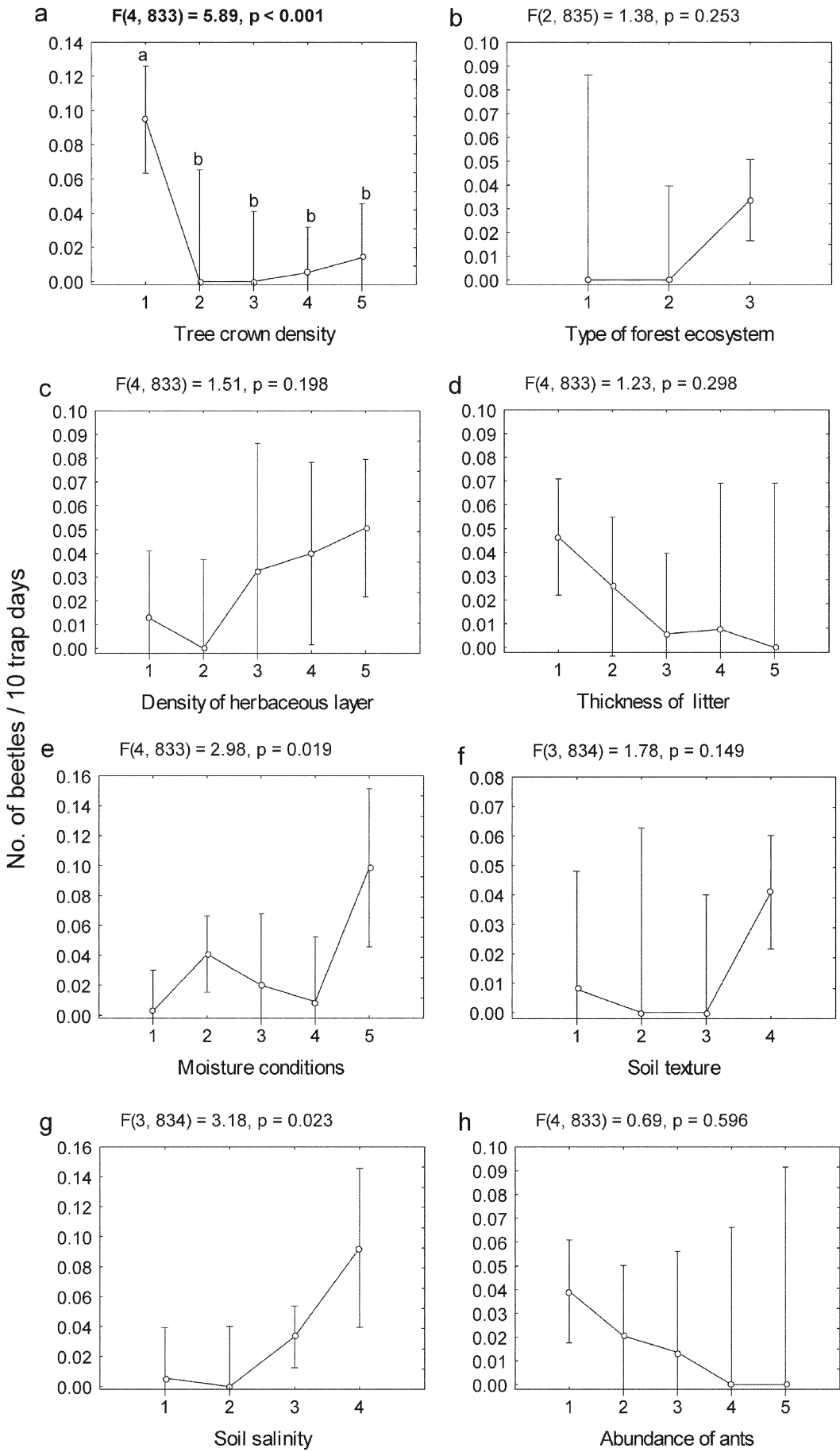

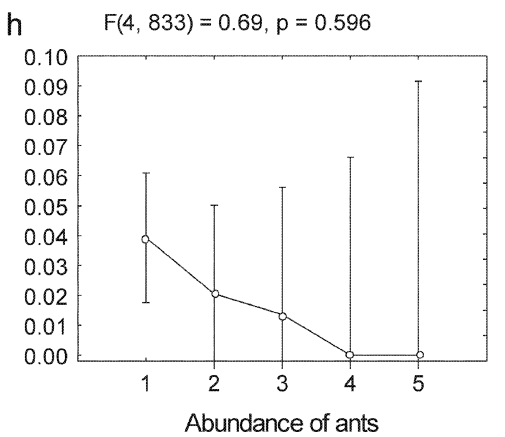

Pterostichus melanarius reached its maximum abundance in deep litter (30-40 mm, Fig. $4 d$ ), in mesohygrophilous moisture conditions (Fig. 5e) and on clay soils (Fig. 5f). The species was also significantly more abundant in decidu- ous forests (Fig. 5b), on soils with a raised level of salinity (Fig. 5g) and in sites with low levels of herbaceous cover $(<20 \%$, Fig. 5 c). Its frequency of occurrence was $20.0 \%$ and its average abundance was $0.49 \pm 2.17$ individuals/10 trap-days. 

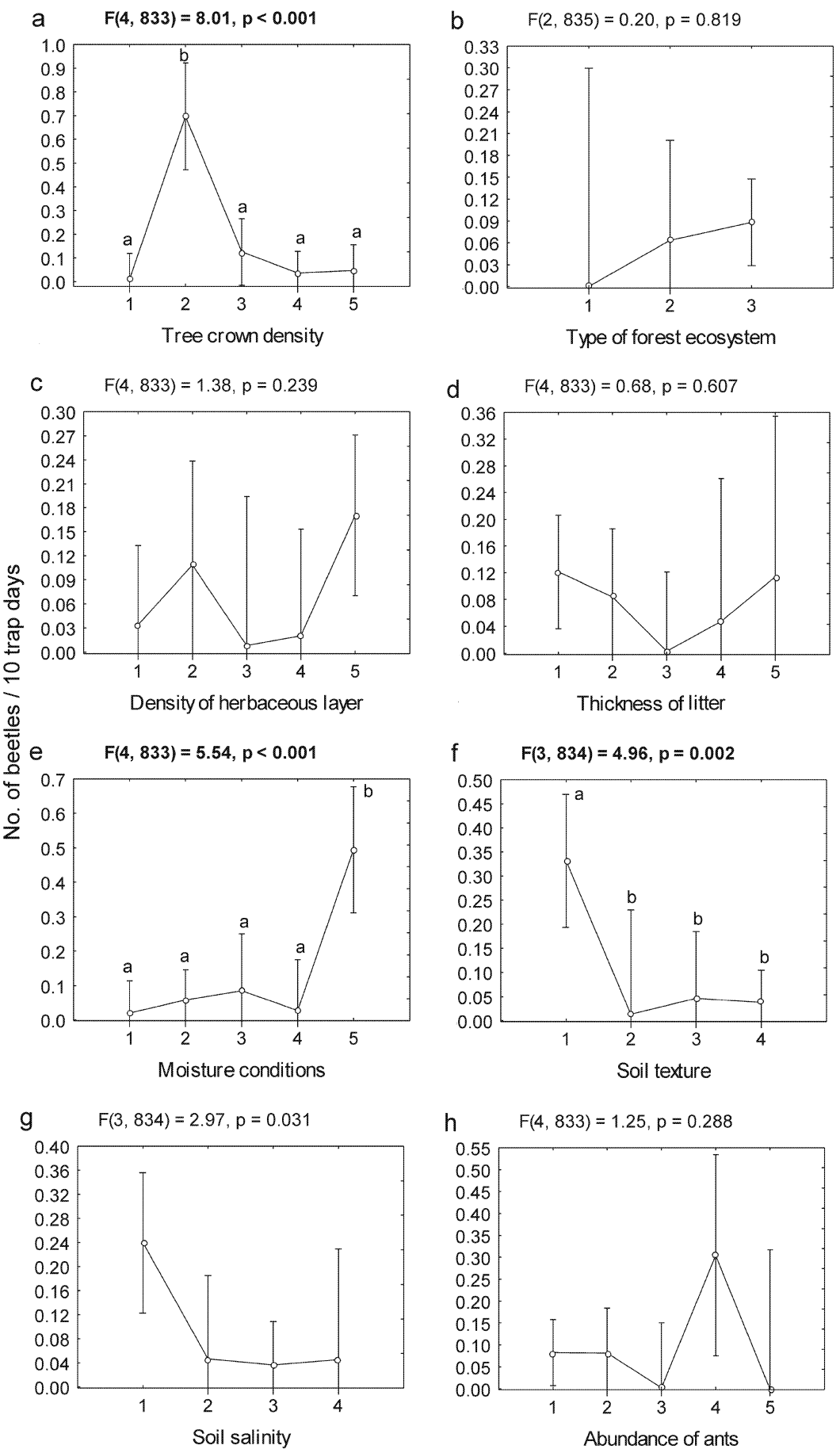

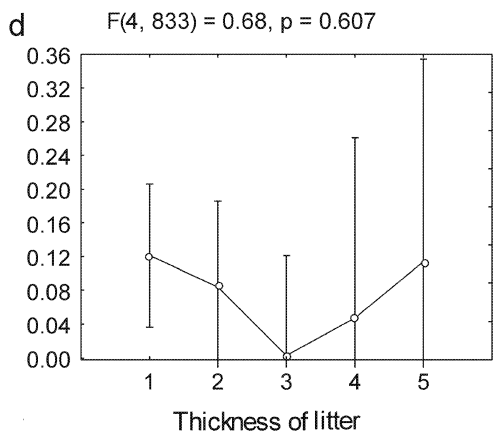

f $\quad F(3,834)=4.96, p=0.002$

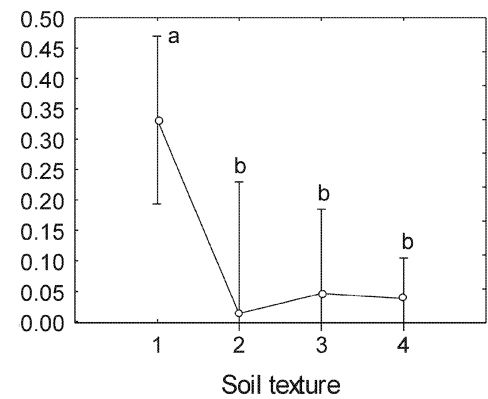

h $\quad F(4,833)=1.25, p=0.288$

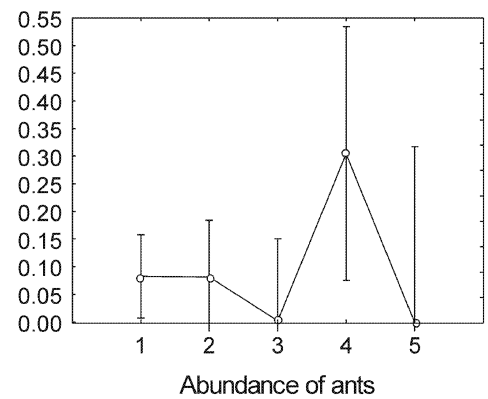

Fig. 3. Association of forest ecosystem conditions with Poecilus versicolor, and results of ANOVAs. For explanations, see Fig. 2.
Pterostichus niger was significantly more abundant in mesohygrophilous and hygrophilous moisture conditions (Fig. 6e) and on sandy loam soils (Fig. 6f). Its frequency of occurrence was $6.9 \%$ and its average abundance was $0.050 \pm$
0.455 individuals/10 trap-days.

Pterostichus oblongopunctatus varied significantly in abundance in relation to 5 out of the 8 analysed ecological factors. Its abundance was higher in conditions of $40-100 \%$ tree crown den- 

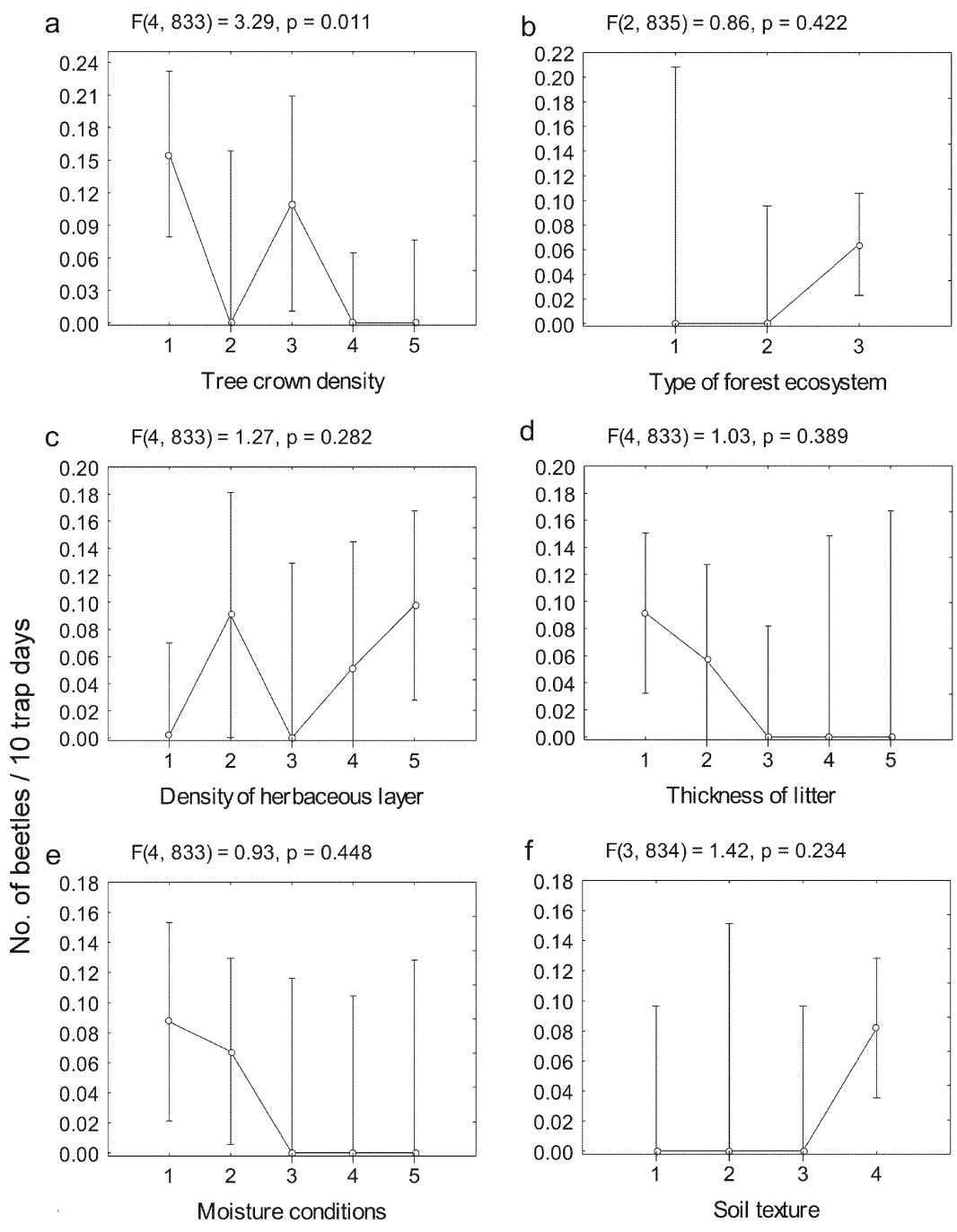

Fig. 4. Association of forest ecosystem conditions with Poecilus sericeus, and results of ANOVAs. For explanations, see Fig. 2.
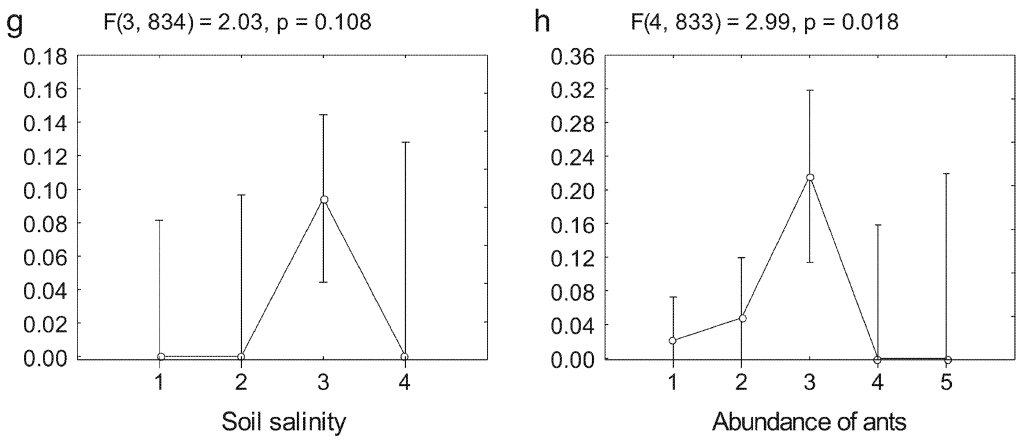

sity (Fig. 7a), loamy soils (Fig. 7f), average soil salinity (Fig. $7 \mathrm{~g}$ ) and thin litter layer (10-20 mm, Fig. 7d). Its frequency of occurrence was $19.5 \%$ and its average abundance was $0.29 \pm 1.33$ individuals/10 trap-days.
In $P$. ovoideus, four out of the eight analyzed factors showed a significant association with the abundance of the species. It reached maximum in sites with low to average litter depth (10-20 mm, Fig. 8d), in hygrophilous moisture conditions 

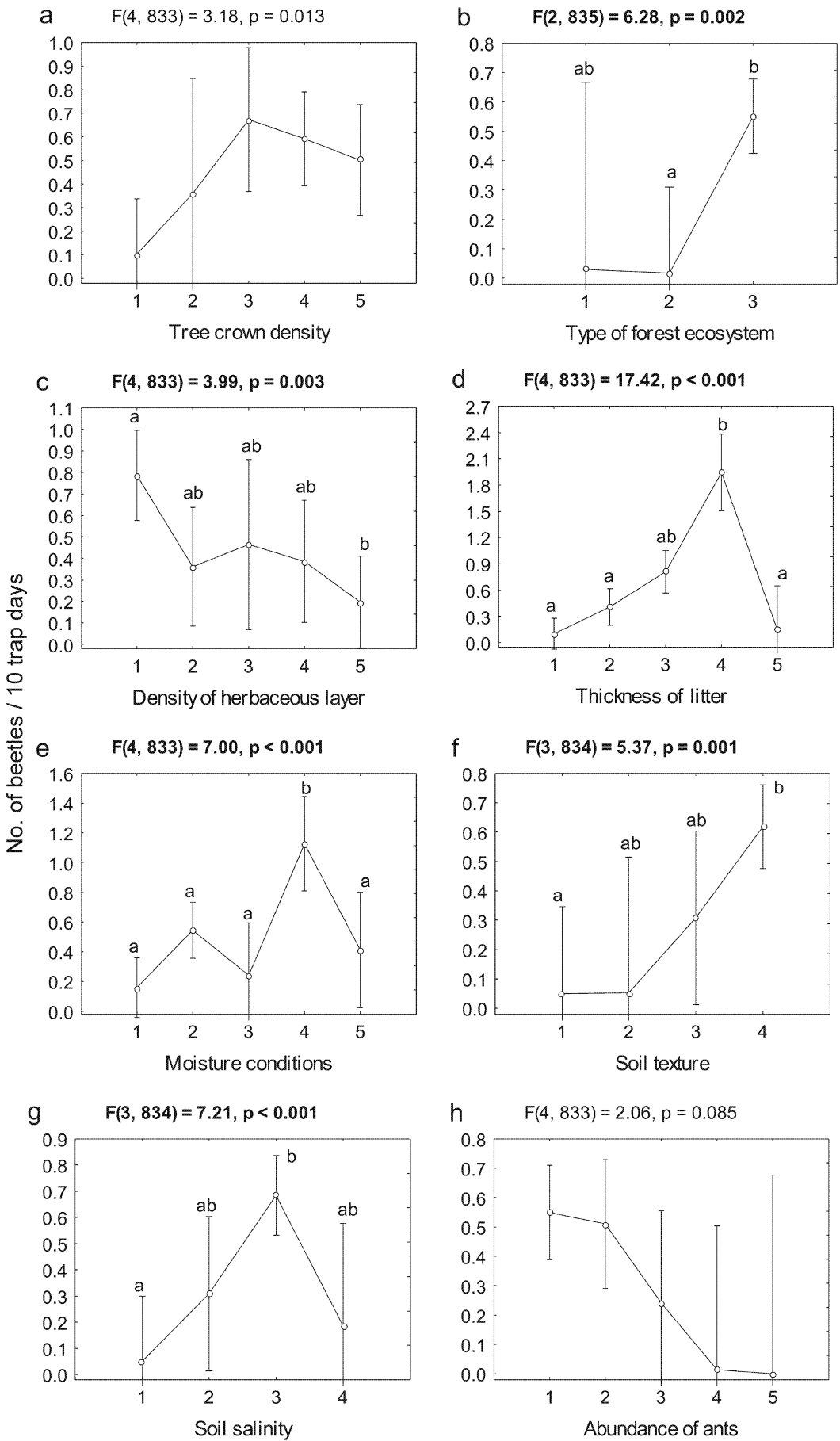

Fig. 5. Association of forest ecosystem conditions with Pterostichus melanarius, and results of ANOVAs. For explanations, see Fig. 2.

(Fig. 8e), on loamy soils (Fig. 8f) of low to average salinity (Fig. 8g). Its frequency of occurrence was $12.4 \%$ and its average abundance was $0.33 \pm$ 2.23 individuals/10 trap-days.

According to the cluster analysis, the greatest similarity in distribution occured between $P$. cupreus and $P$. niger (Fig. 9). The least similarity with other species of ground beetles was observed among $P$. melanarius, $P$. ovoideus and $P$. oblongopunctatus. 

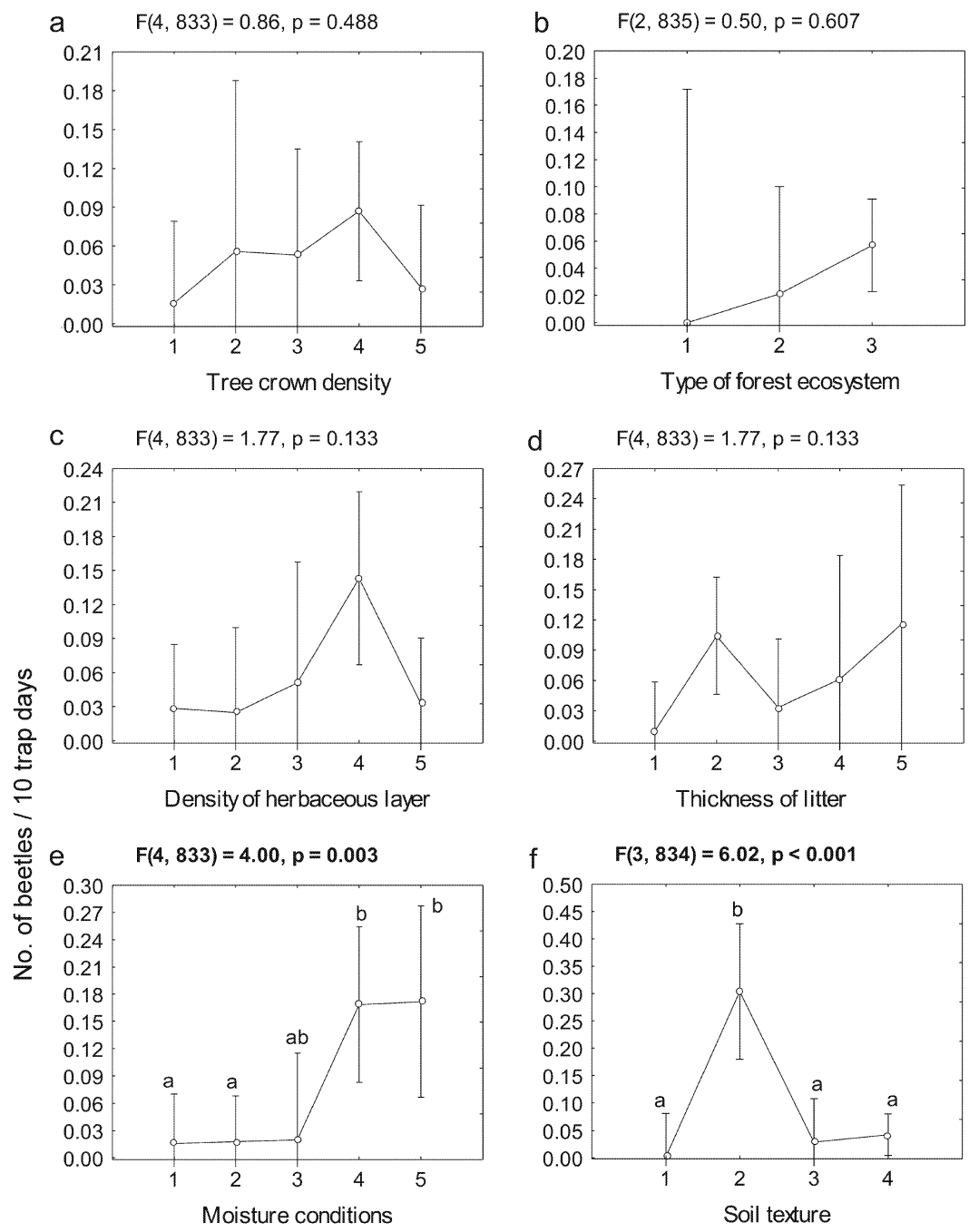

Fig. 6. Association of forest ecosystem conditions with Pterostichus niger, and results of ANOVAs. For explanations, see Fig. 2.

g $\quad F(3,834)=0.61, p=0.607$

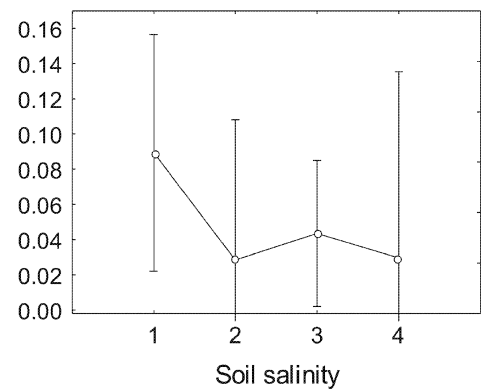

h

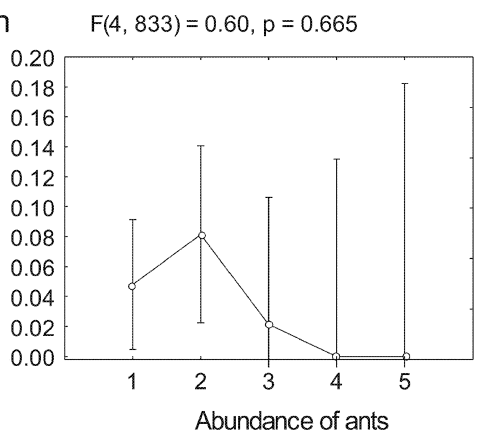

\section{Discussion and review}

\subsection{Poecilus cupreus}

Poecilus cupreus is a West Palaearctic species, reaching Central Siberia and Central Asia (Kry- zhanovskij et al. 1995, Hurka 1996, Freude et al. 2004). It forms the basis of the ground beetle fauna in the fields of Europe and Asia (Kryzhanovskij 1983, Kromp 1990, Lys \& Netwig 1991, Karpova \& Matalin 1993, Soboleva- 

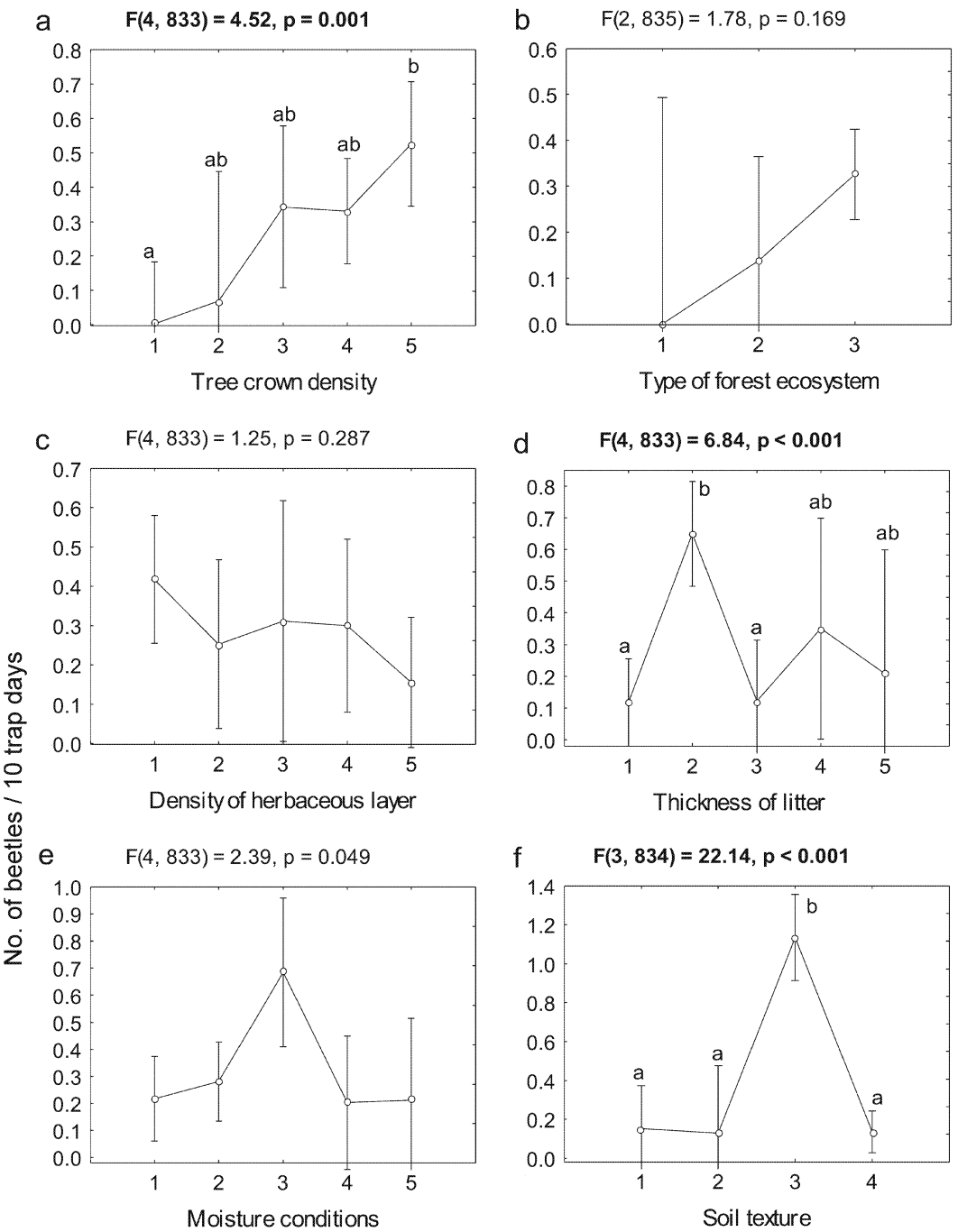

g $\quad F(3,834)=22.42, p<0.001$

h $\quad F(4,833)=1.34, p=0.254$
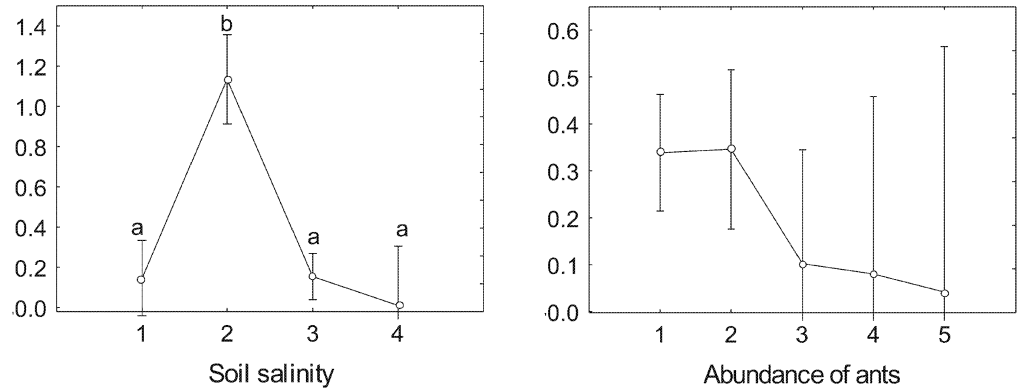

Fig. 7. Association of forest ecosystem conditions with Pterostichus oblongopunctatus, and results of ANOVAs. For explanations, see Fig. 2.

Dokuchaeva 1995, Sharova et al. 1998). According to Lindroth (1986), it is distributed throughout Europe, south to the Mediterranean; Asia Minor; Siberia east to River Lena. In Spain $P$. cupreus is ubiquitous (Serrano 2013). It is spo- radically distributed in the Balkans (Guéorguiev \& Guéorguiev 1995, Hristovski \& Guéorguiev 2015) at altitudes of 0 to $1,300 \mathrm{~m}$. It occurs throughout Ukraine (Putchkov 2011, 2012): P. c. cupreus Linnaeus, 1758 in the Transcarpathian 

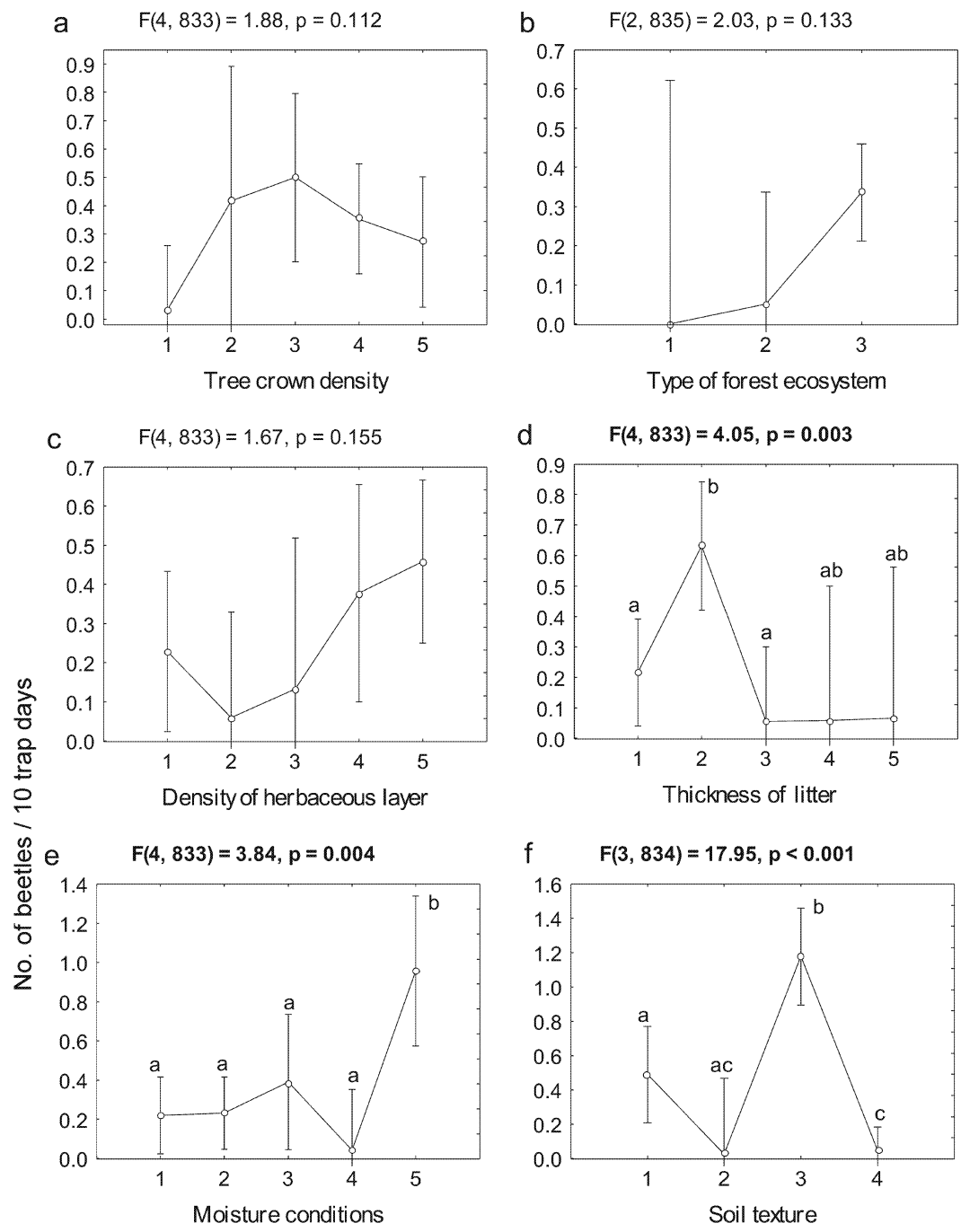

d $\quad F(4,833)=4.05, p=0.003$

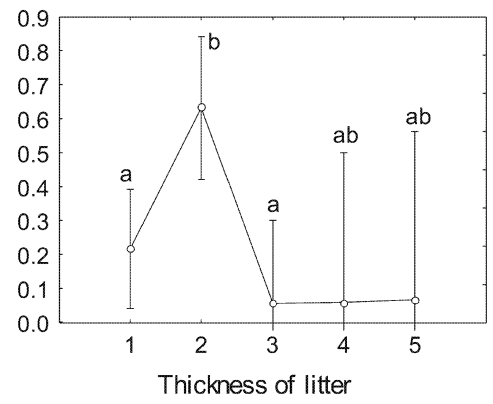

f $\quad F(3,834)=17.95, p<0.001$

Fig. 8. Association of forest ecosystem conditions with Pterostichus ovoideus, and results of ANOVAs. For explanations, see Fig. 2.
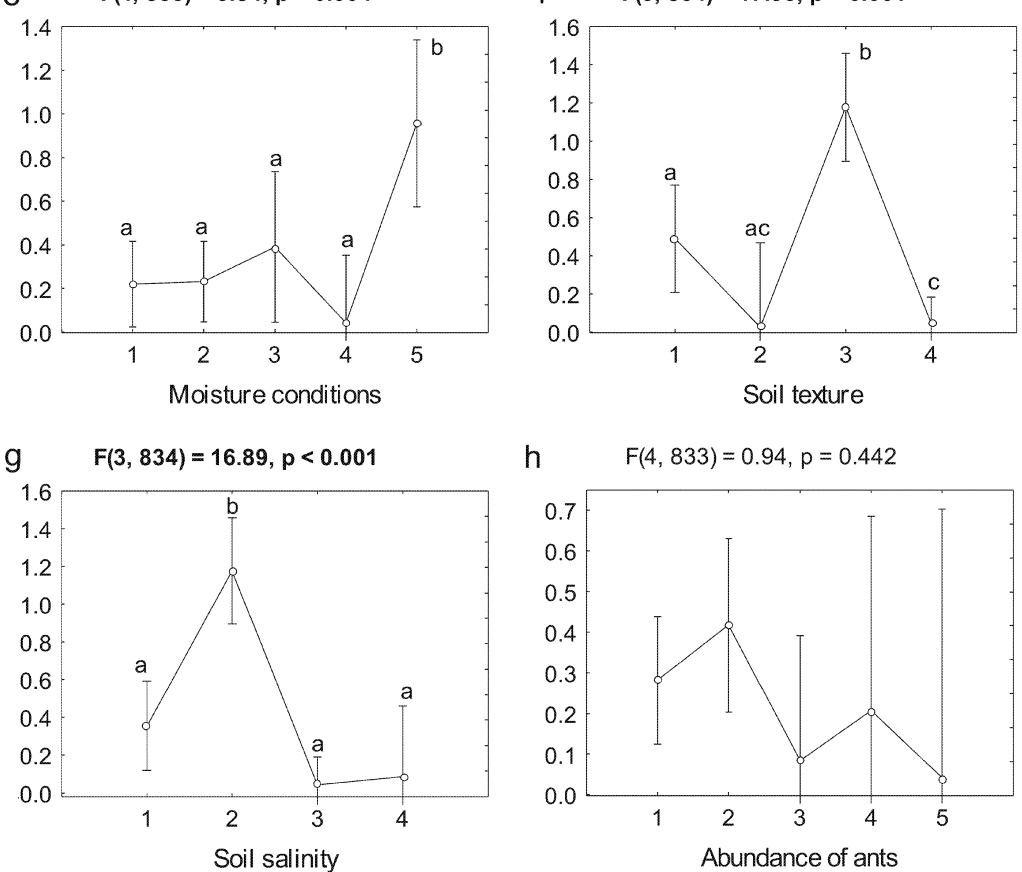

h $\quad F(4,833)=0.94, p=0.442$

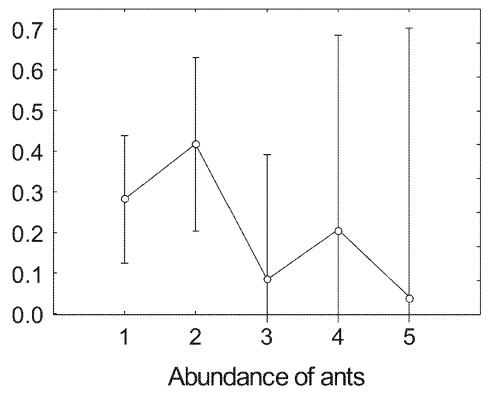

lowland, Carpathian mountains, forest and foreststeppe zone, and $P$. c. dinniki Lutchnik, 1912 in the steppe zone and Crimean peninsula.

In Fennoscandia and Denmark $P$. cupreus is common but local "on open, not too dry meadows and fields, preferably on clayey soil with rather dense vegetation of grasses and sedges" (Lindroth 1986). According to Hellqvist (2014), the species inhabits clayey, not too dry soils in Sweden. 


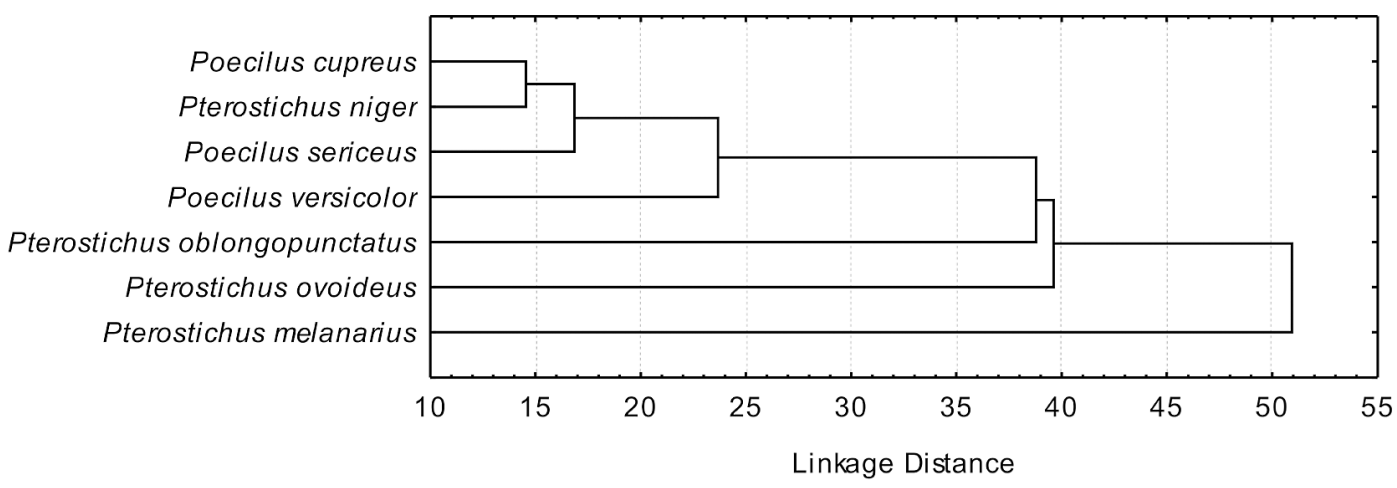

Fig. 9. Results of cluster analysis (single linkage, Euclidean distances) of the distribution of the ground beetle species of the tribe Pterostichini studied in forest ecosystems of the steppe zone of Ukraine.

In Great Britain P. cupreus is found "in open, not too dry meadows and fields, sometimes near water; common, but local" (Lindroth 1974). Luff (1992) states that $P$. cupreus "is common in southern Britain, but much more local in the north and in Ireland. It is found in open, moderately dry and warm habitats such as short grass and agricultural fields".

Hurka (1996) writes that in the Czech and Slovak Republics $P$. cupreus is a "eurytopic species, very common in unshaded habitats: fields, steppe, water edges; lowlands to mountains". It accounted for $2.6 \%$ of the total number of ground beetles collected from Acer campestre, Carpinus betulus and Fraxinus angustifolia forest in the Ranšpurk National Nature Reserve (Southern Moravia) (Šejnohová 2006). In the Bialowieza Primeval Forest (Northern Poland) the species is rare, just $0.1 \%$ of the total count of ground beetles (Sklodowski 2006). In Italy P. cupreus was dominant (over 17\% of the total count of ground beetles) in all restored habitats in an agricultural area of the Po Plain (Pilon et al. 2013).

In Russia, in the Lower Volga Region, P. cupreus is seen "everywhere, often, in agrocoenoses, an abundant species" (Kaljuzhnaja et al. 2000). In the Republic of Adygheya, it is "abundant. A polytopic mesophile which inhabits a wide range of zonal communities, from bottomland areas near floodplain rivers to the subalpine zone. Is often found in agrocoenosis. Flies towards light. Is considered a pest" (Zamotajlov \& Nikitsky 2010). Sigida (1993) states that in Ciscaucasia, the species is a polytopic mesophile, inhabiting steppe areas and pastures, ravine forests and floodplain forests, agricultural and urban landscapes.

In Ukraine $P$. cupreus is an eurybiontic species, which reaches its greatest abundance within the steppe zone in fields and meadows (Brygadyrenko 2000, 2003). It is considered a predator, which sometimes damages sprouted seeds of corn, peas, haricot, beet, garden radish, clover, lucerne, maple, hornbeam, ash, young sprouts of potatoes, fruit pulp of strawberries, tomatoes, and fallen fruit in gardens (Petrusenko \& Petrusenko 1973). In the southern part of its range, in Ukraine's steppe zone, the species occurs in all types of ecosystems: from shores of reservoirs, including salines (Brygadyrenko 2000), to xeromesophilous and mesoxerophilous steppe sites and sparse, dry plantations (Brygadyrenko 2003). Here its range of moisture preferences is very wide. The thickness of litter in different sites inhabited by $P$. cupreus also differs: from complete absence of litter on agricultural fields and areas of sand steppe, to thick shoreline drifts of decaying Phragmites australis (Cav.) Trin. ex Steud. Only a small proportion of the $P$. cupreus populations in the steppe zone of Ukraine inhabits forests; more individuals are recorded annually in fields and near water. Because of the species' well-developed flight capacity, one cannot consider the forest individuals of this species to belong to separate populations or subpopulations. Our data contained positive correlation of the species' abundance with sparse tree crown cover. This correlation was found to be very strong. 